Volume 1

Number 2 Secrecy and Authoritarianism

Article 11

February 2018

\title{
Review, Doom Towns: The People and Landscapes of Atomic Testing, A Graphic History
}

Susan Maret

San Jose State University, drsmaret@gmail.com

Follow this and additional works at: https://scholarworks.sjsu.edu/secrecyandsociety

Part of the International Law Commons, Public Affairs, Public Policy and Public Administration Commons, and the Sociology Commons

\section{Recommended Citation}

Maret, Susan. 2018. "Review, Doom Towns: The People and Landscapes of Atomic Testing, A Graphic History." Secrecy and Society 1(2). https://doi.org/10.31979/

2377-6188.2018.010211 https://scholarworks.sjsu.edu/secrecyandsociety/vol1/iss2/11

This Book Review is brought to you for free and open access by the School of Information at SJSU ScholarWorks. It has been accepted for inclusion in Secrecy and Society by an authorized administrator of SJSU ScholarWorks. For more information, please contact scholarworks@sjsu.edu.

\section{(c) (1)}

This work is licensed under a Creative Commons Attribution 4.0 License. 


\section{Review, Doom Towns: The People and Landscapes of Atomic Testing, A Graphic History}

\section{Keywords}

AEC, Cold War, graphic novels, nuclear fallout, nuclear testing, nuclear weapons, radiation risk 


\section{Review, Doom Towns: The People and Landscapes of Atomic Testing, A Graphic History,}

by Andrew G. Kirk

Reviewed by Susan Maret

Doom towns: The people and landscapes of atomic testing, a graphic history, illustrated by Kristian Purcell. New York: Oxford University Press, 2016. 384 pp. / ISBN: 9780199375905 (paperback) / https://global.oup.com/ushe/product/doom-towns-9780199375905? $\mathrm{cc}=$ us\&lang=en\&

Doom Towns is the story of nuclear testing and Cold War atomic culture told in graphic novel form. ${ }^{1}$ The author, historian Andrew G. Kirk, is Professor of Environmental and Western History, University of Nevada, Las Vegas. To capture the turbulent history of the atomic age, Kirk found inspiration in two graphic novels: Art Spiegelman's powerful Maus and the remarkable Alan's War, written by Emmanuel Guibert. Artist Kristian Purcell contributed illustrations to Doom, which bring drama and emotion. Purcell studied the NNSA/DOE nuclear archives and other historical sources that bring richness to primary materials, declassified government documents, and oral histories from the Nevada Test Site Oral History Project. The Oral History Project, established by Kirk with assistance from graduate students, is a "primary source database of lived experience" (Kirk 2016, xxiv).

In triangulating multiple sources, Doom offers the reader a glimpse into 
several worlds: the controversy over the Cold War arms race, global nuclear weapons testing, U.S. national security paranoia, and groupthink. Kirk views his graphic story as public or applied history, but Doom is also public health history in that traces the evolution of radiation standards, the notion of an "acceptable" exposure to radiation, and scientific understanding of fallout on the foodchain and ecosystems. $^{2}$

Secrecy is a running theme throughout Doom Towns, particularly the official secrecy that bound Manhattan Project scientists and atomic workers caught up in "patriotism, stoicism, and pride" (Kirk 2016, xix). This type of secrecy is typified by the Moynihan Commission, who identified the concealment of information with a vortex of other factors such as industrial security, national defense, compartmentation of science, and "the enemy abroad, the enemy within" (Commission on Protecting and Reducing Government Secrecy 1997). ${ }^{3}$ I characterize this particular type of secrecy as nuclear secrecy, or

The intentional blocking, compartmentalizing, concealment, control, distorting, hoarding, censoring, and manipulation of information related to the numerous dimensions of historic and ongoing atomic or nuclear fuel cycle activities, including access to information related to pollution, risk, public health, waste, war, and weapons development. Nuclear secrecy is institutionalized through bureaucratic organization, statute, regulation, decree, security classification of information, language, control of the media, and informal practices, carrying with it some type of penalty for disclosure such as harassment, monetary fines, incarceration, and other means of silencing individuals. ${ }^{4}$

In the United States, nuclear secrecy ranges from historically withholding public knowledge of nuclear weapons tests (e.g., National Security Memorandums 176 and 347$)^{5}$ to information that is "born classified" under the Atomic Energy Act 
of 1946 and 1954. But nuclear secrecy is not an artifact of the past. A recent publication reports that concealment of nuclear weapons programs and weapons systems is "an obstacle both for assessment and accountability pertaining to nuclear risk" (Borrie, Caughley, and Wan 2017). ${ }^{6}$

\section{Unraveling Atomic History: The Graphic Approach}

One of the images of the nuclear age is the proverbial genie out of the bottle. That is, the knowledge of the atom "cannot be disinvented; the real secret of nuclear weapons is that they can be built, and that knowledge is part of human culture... what do societies do with genies that they cannot get back into bottles?"(Beckman 1992, 21). ${ }^{7}$ Doom Towns discusses the atomic genie in nine chapters that, among other subjects, provide a snapshot history of atmospheric and underground nuclear testing by the U.S., ${ }^{8}$ Former Soviet Union (FSU), and UK. ${ }^{9}$ Below, I offer highlights of each chapter of Doom.

Chapter 1, "Trinity," begins with the rush to develop the atomic bomb twenty one days before the destruction of Hiroshima and Nagasaki. In this chapter, we are introduced to one of the novel's narrators, The New York Times reporter Gladwin Hill, "the dean of atomic reporters" (Mr. Hill's narration is in yellow text boxes throughout Doom). Chapter 2, "Crossroads," retraces the tragic history of the evacuation of 42,000 native peoples from the Bikini Atoll in anticipation of the 1946 Operation CROSSROADS tests (ABLE and BAKER). The chapter includes details on the founding of the Federation of America Scientists (FAS) by Manhattan Project scientists, who created one of the most powerful 
symbols of the nuclear age, the Doomsday Clock. ${ }^{10}$ "Crossroads," also notes the quest to understand "acceptable" radiation exposure as well as develop protective radiation standards. The passage of the Atomic Energy Act of 1946 (P.L. 79-585), which created the Atomic Energy Commission (AEC), is also included in the chapter.

Chapter 3, "Nutmeg," includes discussion of the Soviet Polygon, where 400 nuclear explosions were conducted above ground from 1949 to 1989 at Semipalatinsk, Kazakhstan. ${ }^{11}$ This chapter is significant for its reenactment of discussions between the military and AEC on the siting of a U.S. based continental test site, with the Commission concluding such a site was not "desirable" (Kirk 2016, 43). The discussion of the once secret Armed Forces Special Weapons Project (AFSWP) research study of five U.S. based locations code-named "Project Nutmeg" is worth noting here for its public information campaigns that emphasized radiation safety and "precautions." In reality, the AFSWP, which grew out of the "specifically military remnants of the Manhattan Project," suffered from the blindness that is technological optimism in its belief that under "'proper meteorological conditions,'" continental nuclear weapons testing would "'result in no harm to populations, economy, or industry'" (Fehner and Gosling 2000, 40). ${ }^{12}$

Chapter 4, "Ranger," discusses the 1863 Treaty of Ruby Valley, which granted limited use of Western Shoshone native lands to the U.S government. Here Kirk and Purcell challenge the notion this native land was devoid of wildlife, long term habitation, and culture. Other topics surveyed in this chapter include 
the discussion of estimated radiation exposure from the ABLE (January 27, 1951) and BAKER (January 28) detonations at the Nevada Test Site (NTS) ${ }^{13}$

In this section of Doom, we also see atomic planners thinking out loud in estimating "twenty-five roentgens is the limit for persons not exposed to radiation in the course of operations. Same is true for the general public" (Kirk 2016, 54). ${ }^{14}$ As Doom reports, initially radiation badges were only issued to "the most critical personnel" (Kirk 2016, 54); however, film badges were subsequently found to be "insensitive, however, to neutron radiation and did not measure the amount of radioactive material, if any, that may have been inhaled or ingested" (Maag, Rohrer and Shepanek 1982). ${ }^{15}$ Five thousand soldiers witnessed Operation BUSTER-JANGLE in fall of 1951 in order to test the effects of detonations on American servicemen. These atomic age soldiers camped in foxholes and trenches on the Nevada Test Site. As Kirk $(2016,60)$ digs from the archive, the "real experiment at Desert Rock was on the soldiers' minds." Chapter 4 concludes with details of Operation Ivy, conducted November 1952 at the Eniwetok Atoll in the Marshall Islands, and MIKE, the first H-bomb test, detonated in November, 1952.

Chapter 5, "Doom Town," picks up with the MIKE test, which blasted "the island of the atoll" out of existence (Kirk 2016, 65). Reporter Gladwin Hill shares details of his visit to the Nevada Proving Ground (NPG) to witness a series of tests, including GRABLE, fired by a cannon and yielded 15 kilotons. Hill describes a "Doom Town" built for OPERATION DOORSTEP on Yucca Flat that allowed the Federal Civil Defense Agency (FCDA) to study the impacts of "atomic blasts on civilian infrastructure" during the UPSHOT-KNOTHOLE test (Kirk 2016, 66). This 
doom town featured typically suburban homes stationed 3,500-7,500 feet from the bomb tower. Mannequins were placed fully dressed in clothing provided by JC Penny within "doom" homes and "rudimentary" bomb shelters and cars to mimic a (white middle class) American family in the event of a nuclear attack. In this atomic Potemkin Village, cameras were placed throughout the homes, with FCDA promoting an odd sort of publicity and transparency. FCDA, as Kirk $(2016,71)$ notes, was "confident these experiments will answer the public's questions that we are making every effort to promote extensive and vivid coverage as possible by all media." ${ }^{16}$ Bordering on the macabre, the subsequent test ENCORE included of fifty-five shaved pigs dressed in military uniforms "placed at varying distances from GZ" as their skin was "similar to human flesh" (Kirk 2016, 75). When offsite radiation monitors exceeded estimated radiation dosages, officials offered a free car wash to citizens, who were advised "not to worry" (Kirk 2016, 76). Officials later commented that "no one questioned authority" after this and other "safety" interventions (Kirk 2016, 76).

Chapter 6, "Fallout," continues the narrative of UPSHOT-KNOTHOLE, specifically the failed modeling of HARRY test, which "ended with a bigger bang than the AEC boys anticipated" and carried radioactivity downwind to St. George, Utah (Kirk 2016, 79-80). Meanwhile, anomalies were reported by ranchers, whose sheep and horses died from possible radiation exposure (Kirk 2016, 8182). These critical events led to "lowering the standard offsite exposure to 3.9 roentgens over 13 weeks to the same amount over an entire year" (Kirk 2016, 82). ${ }^{17}$ Tests at the NPG and the Bikini Atoll continued with news of the FSU's 
detonation of their first hydrogen bomb on August 12, 1953, and British nuclear tests in the Woomera Test Range, Australia (Kirk 2016, 82). On March 4, 1954, CASTLE-BRAVO was conducted in the Pacific where "a blizzard of white powder fallout" enveloped soldiers, scientists, the eighty-two residents of Rongelap, and the twenty-three person crew of the Japanese fishing boat, Fukuyu Maru (Kirk 2016, 84-86).

Chapter 6 also notes the discovery of the bone-seeking radioisotope Strontium-90 in fish sold in Japan (Kirk 2016, 86-87). With a nod to ecologist Eugene Odum's pioneering work, Times reporter Gladwin Hill breaks into the story at this point in the novel to discuss fallout studies and the "byproducts of atomic testing" and their effect on human health and ecosystems (Kirk 2016, 88). The story continues with TEAPOT, the series of tests following BRAVO that raised additional concerns with the medical and biological effects of weapons fallout; Hill mentions the 1954 Project GABRIEL study that researched the impact of fission products in the environment and radiation exposure. ${ }^{18}$ Here Kirk $(2016,89)$ mentions AEC's secret Project SUNSHINE that measured Strontium-90 in human tissues, including infant bones. Declassified SUNSHINE documents reveal the AEC's role in clandestine "body snatching" in order to conduct its study. ${ }^{19}$ In addition to the aforementioned subjects, Chapter 6 discusses tests conducted at the NTS under TEAPOT, APPLE-2, and Operation CUE. Las Vegas casinos held "parties to watch the shots light up the early morning sky" (Kirk 2016, 91). The following WIGWAM detonation was conducted in May, 1955 "in open water," five hundred miles from the California coast; the 1956 Operation 
REDWING "aimed at weapons improvements" (Kirk 2016, 92). The chapter concludes with a contrast between the July 9, 1955 Russell-Einstein Manifesto and the Eisenhower administration's July 21, 1955 Open Skies program. ${ }^{20}$ Drafted by eminent scientists who opposed the testing and use of weapons of atomic weapons, the Manifesto called for the

governments of the world to realize, and to acknowledge publicly, that their purpose cannot be furthered by a world war, and we urge them, consequently, to find peaceful means for the settlement of all matters of dispute between them. ${ }^{21}$

Chapter 7, "Boltzmann," is titled after Austrian physicist Ludwig Boltzmann, who holds the dubious honor of having an Operation PLUMBOB detonation named for him (Kirk 2016, 94-96). PLUMBOB stands as the longest nuclear test in history, running from May-October 1957, with twenty-four shots and a literal army of "eighteen thousand DoD personnel and 6 thousand citizen civil defense community monitors" in attendance (Kirk 2016, 98). Radiation safety was the "principal concern" of the PLUMBOB series (Kirk 2016, 103). Portions of this chapter are narrated by reporter Gladwin Hill and scientist William Geagley, chief chemist of the Michigan State Department of Agriculture from the $1930-1970 .{ }^{22}$ Geagley was invited to participate in the FCDA's Radiological Defense Operation program, where the subject of fallout was a major focus - attendees were encouraged to return home "to quiet irrational fear" (Kirk 2016, 100).

Chapter 7 also includes a playoff of testimonies from the 1957 Nature of Radioactive Fallout and its Effects on Man hearings between AEC Commissioner Willard F. Libby and Dr. Charles L. Dunham, Director of the AEC's Division of 
Biology and Medicine division. ${ }^{23}$ Libby implored that "the very small and rigidly controlled risk posed by fallout pales in comparison to risk of annihilation," and cites National Academy of Science recommendations of 3.9 roentgens per twelve months maximum radiation exposure (Kirk 2016, 101). Dunham's comments from the hearings include a puzzling statement that "the many thousands of people living in the testing region are difficult to categorize as individual persons" (Kirk 2016, 101). When asked about the nature of a permissible exposure to radiation, Dunham replied that it "lies somewhat between 10 and 50 roentgens per 30 year limit" (Kirk 2016, 101). ${ }^{24}$

The remainder of Chapter 7 is narrated by Gladwin Hill, who investigated the link between radiation and leukemia in residents living near NTS. Hill also reports on PRISCILLA, the "largest military effects tests ever conducted" with 1,700 troops, hundreds of observers, 719 pigs, mice, and Dalmatians in attendance (Kirk 2016, 105). The HOOD, Shot JOHN, and DIABLO detonations (Kirk 2016, 106-7) are also noted in the chapter. Chapter 7 concludes with An Appeal by American Scientists to the Governments and People of the World (Kirk 2016, 108). The one page December 1957 Appeal was drafted by Linus Pauling, Barry Commoner and Edward Condon, and called for an international agreement to stop the testing of nuclear bombs now could serve as a first step toward a more general disarmament and the ultimate effective abolition of nuclear weapons averting the possibility of a nuclear war that would be a catastrophe to all humanity. ${ }^{25}$

Chapter 8 "SMOKY" begins with Gladwin Hill narrating the fifteenth atmospheric test in the 1957 PLUMBOB series, which included 20,000 troops 
stationed at Desert Rock, and an additional 5,800 troops positioned around the 1,900 yard diameter of ground zero (Kirk 2016,110). The chapter reports on the RAINIER underground test facility, touted as a means to "have our cake or eat it too, better weapons without concern about fallout." In other words, atomic policymakers thought it was possible to continue nuclear detonations without breaking the Limited Ban Treaty (Kirk 2016, 111-112).

In chapter 8, we see Ernest O. Lawrence and Edward Teller lobby the Eisenhower administration for continued nuclear testing (Kirk 2016, 114), with Kirk $(2016,116)$ portraying the 1958 HARDTACK tests as the "beginning of the end of atmospheric testing. ${ }^{26}$ At this point, Doom notes the Limited Test Ban Treaty was signed by parties in Moscow on August 5, 1963, with the Senate ratifying the Treaty on September 23, 1963 by an 80-19 margin. President Kennedy signed the Treaty into law on October 7, 1963 (Kirk 2016, 117; the date for the presidential signing is cited as September 24 in Doom). ${ }^{27}$ Looking back from the $21^{\text {st }}$ century, it is almost impossible to fathom that during this time period the "average rate of testing was approximately once a week during the Cold War and peaked at 175 tests in 1962, the year prior" to the Kennedy administration's Limited Test Ban Treaty (Maceira, et al, 2017, 11). ${ }^{28}$

The subsequent 815 underground nuclear tests gave way to protest, with "lawyers, scientists, and ordinary citizens who ultimately pushed federal agencies to release classified information amount radiation exposure an health effects" (Kirk 2016, 118). For instance, the 1970 BANEBERRY released approximately 80,000 curies of radioactive Iodine- 131 in fallout that was carried into several 
states, including Utah and Arizona. It is interesting to note that the Treaty on the Non-Proliferation of Nuclear Weapons, which entered into force in 1970 and ratified by several nuclear states, is not discussed in Doom. ${ }^{29}$

The graphic portion of Doom Towns concludes with Chapter 9, "Secrecy and History." Chapter 9 includes discussion of the last test at NTS in 1992 (DIVIDER under Operation Julin), with President Clinton signing the Comprehensive Test Ban Treaty in 1996 (Kirk 2016, 122). Here Kirk recognizes the profound impact of citizen protests, the anti-nuclear movement, and indigenous peoples in "testing nations" that paved the way for curtailment of nuclear weapons testing (Kirk $2016,122-23,128)$. However, the insertion of the former Yucca Mountain Nuclear Waste Repository into the discussion is confusing. Yucca Mountain is proposed as a storage facility for spent fuel generated by U.S. nuclear power plants. ${ }^{30}$

The remainder of chapter 9 discusses "official secrecy and restricted access" to government publications on the subject of nuclear testing (Kirk 2016, 124). Kirk notes the importance of the 1987 case Irene Allen v. the United States that not only broke through the myth of no harm from exposure to radioactive fallout, but questioned the liability of the U.S. government for radiation-induced illnesses stemming from fallout (Kirk 2016, 125). In this chapter, we note the passing of one of Doom's narrators, William Geagley, who died of leukemia in 1971 (Kirk 2016, 126).

Among other subjects included in chapter 9 are the Department of Energy's (DOE) OpenNet digital archive, established in 1992 as part of the Clinton administration's revision of declassification policies, which included the DOE's 
Openness Initiative (Kirk 2016, 127). The graphic portion of Doom Towns concludes with a reminder that much of the story of nuclear testing remains to be told (Kirk 2016, 130).

\section{Supplementary Materials}

Doom Towns includes a plethora of supplementary materials. Part 2 lists primary materials by chapter, and Part III is an essay on "Historical Context." Additional supplementary materials include a "cast of characters," which introduces Doom's major actors. Maps and figures, a questions section for course and student use, a comprehensive bibliography of primary and secondary materials, timeline of atomic testing, and glossary round out Doom. These supplements add value to the text, especially for readers unfamiliar with U.S. and global nuclear history.

\section{Several Issues}

The novel suffers from several challenges. First, there is no index, which makes it difficult to quickly locate, for example, major scientists and atomic tests. Secondly, readers unfamiliar with the history and culture of the period may have difficulty recognizing historical figures (e.g., Jawaharlal Nehru, first Prime Minister of India, on page 87). Moreover, some dates are not necessarily chronological within panels, which causes a problem with reading flow (e.g., in one section November 1953 is listed in a top panel with an August 12 date in the lower). In addition, Part III titled "Historical Context," might be better served by relocation 
to the beginning of the text as to offer readers an additional foundation for content discussed within the graphic novel. Lastly, it is difficult to pinpoint exact primary and secondary sources mentioned in the graphic portion of the text within the supplementary materials.

As Doom Towns centers on "the people and landscapes of atomic testing," there would be benefit in mentioning a few details from the period on the government secrecy establishment. For example, a brief mention of secret human experimentation with plutonium and other radioactive substances, the polluting aspects of the historical and current nuclear fuel cycle, and how the former AEC current DOE national labs-weapons complex remains responsible for radioactive waste and pollution offsite (e.g., Los Alamos, Rocky Flats) are certainly residuals

of the atomic age. ${ }^{31}$ Moreover, some commentary of how atomic testing and subsequent fallout - and the congressional hearings on the subject long after testing ceased - would have reinforced Kirk's documentation of the thinking of the period on risk and safety. One example is the public heath impacts of fallout on thyroid disorders and the National Cancer Institute's (NCI) delayed study. ${ }^{32}$

\section{The Timeliness of Doom Towns}

Organizational and content issues aside, Doom Towns is a noble effort in terms of Kirk's ability to condense a woefully complex subject down to size. Doom's graphic approach lends itself to a necessary Cold War re-telling, and makes the story of nuclear testing even a more urgent tale with the recent United Nations' Treaty on the Prohibition of Nuclear Weapons. The July 7, 2017 Treaty is 
not only a somber reminder of the horror of nuclear weapons, but questions their very existence. ${ }^{33}$ One hundred twenty-two nations initially endorsed the Treaty, with Japan, Australia, and critical "nuclear-weapon States" such as the Russian Federation and the United States noticeably absent from negotiations. ${ }^{34}$ The United States, United Kingdom, and France issued a joint statement claiming the Treaty "clearly disregards the realities of the international security environment." ${ }^{135}$

I thank Daniel Hirsch, president of the Committee to Bridge the Gap, and former director of the Program on Environmental and Nuclear Policy at UC Santa Cruz, for his comments on historic radiation exposure limits. 
1 There are obvious differences between atomic and nuclear weapons; atomic weapons are fission (used in Nagasaki and Hiroshima) and the H-bomb is thermonuclear. For simplicity's sake, in this review I use atomic and nuclear interchangeably.

2 That decades later, science is only fully beginning to understand. See T. I. Gombosi, D. N. Baker, A. Balogh, P. J. Erickson, J. D. Huba, and L. J. Lanzerotti, "Anthropogenic space weather" (Space Science Review, 2017: doi: 10.1007/s11214-017-0357-5).

3 Commission on Protecting and Reducing Government Secrecy (1997), Appendix A, "A culture of secrecy" at https://fas.org/sgp/library/moynihan/

4 See Susan Maret, On their own terms: A lexicon with an emphasis on information-related terms produced by the U.S. federal government. 5th edition, revised fall 2016.

http://www.fas.org/sgp/library/maret.pdf

5 NSAM 176, Release of public information concerning Soviet nuclear tests, https://www.jfklibrary.org/Research/Research-Aids/Ready-Reference/National-SecurityMemoranda.aspx and Johnson administration NSAM 347, https://fas.org/irp/offdocs/nsam-lbj/, limited public information on foreign nuclear tests.

6 Borrie, John, Tim Caughley, and Wilfred Wan, eds. Understanding nuclear weapon risks. UNDIR, 2017. http://www.unidir.org/files/publications/pdfs/understanding-nuclear-weaponrisks-en-676.pdf

7 Beckman, Peter R. 1992. "Sociology and nuclear weapons" (Sociological Forum 7, no.1: 7-27).

8 A recent working paper estimates "that fallout from nuclear testing contributed between 340,000 to 460,000 excess deaths from 1951 to 1973." See Keith A. Meyers, "Some unintended fallout from defense policy: Measuring the effect of atmospheric nuclear testing on American mortality patterns," https://www.keithameyers.com/research/

9 Tests conducted by France and China are not fully discussed in Doom. For example, from 1960 to 1996, France conducted 17 tests in the Algerian Sahara and 193 tests in French Polynesia, with the end result that "plutonium fallout hit the whole of French Polynesia, a much broader area than France had previously admitted. Tahiti was exposed to 500 times the maximum accepted levels of radiation." See Angelique Chrisafis, "French nuclear tests 'showered vast area of Polynesia with radioactivity," The Guardian July 3, 2013, https://www.theguardian.com/world/2013/jul/03/french-nuclear-tests-polynesia-declassified

China conducted forty-five nuclear tests; see the CTBTO Preparatory Commission, https://www.ctbto.org/nuclear-testing/the-effects-of-nuclear-testing/chinas-nuclear-testingprogramme/

10 The clock is maintained by FAS with midnight designating global catastrophe. As I write this review, the Clock is positioned at two minutes to midnight. See https://thebulletin.org/2018doomsday-clock-statement

11 See Tina M. Carlsen, Leif E. Peterson, Brant A. Ulsh, Cynthia A. Werner, Kathleen L. Purvis, and Anna C. Sharber, "Radionuclide contamination at Kazakhstan's Semipalatinsk test site:

Implications on human and ecological health" (Human and Ecological Risk Assessment 7, no. 4 (2001): 943-955, http://ur1.ca/qzvye ); Also see Rustam Qobil, "Soviet-era nuclear testing is still making people sick in Kazakhstan," PRI March 13, 2017, https://www.pri.org/stories/201703-13/soviet-era-nuclear-testing-still-making-people-sick-kazakhstan

12 See their Origins of the Nevada Test Site (Washington, DC: U.S. Department of Energy, 2000), 
Secrecy and Society, Vol. 1, No. 2 [2018], Art. 11

https://www.osti.gov/scitech/biblio/769471-TVSYD0/webviewable/

13 Historically the site had different names over the years: Site Mercury (1950-51), Nevada Test Site (1951-52), Nevada Proving Ground (1952-54), NTS (1955-2010), Nevada National Security Site (2010-). See United States nuclear tests July 1945-September 1992 (DOE/NV209-REV 16, September, 2015), https://www.nnss.gov/docs/docs LibraryPublications/DOE NV209 Rev16.pdf

14 Roughly equivalent to 12,500 chest X-rays.

15 See Carl Maag, Stephen Rohrer, and Robert Shepanek. Operation RANGER, Shots ABLE, BAKER, EASY, BAKER-2, FOX, 25 January-6 February 1951 (JRB Associates Inc: McLean, VA: 1982), http://www.dtic.mil/dtic/tr/fulltext/u2/a118684.pdf

16 FCDA characterized fallout as "nothing more than particles of matter in the air" in a 1955 publication Facts About Fallout, at my blog, https://atomichistory.wordpress.com/2009/08/16/facts-about-fallout-1955/

173.9 Roentgens per year is still above current regulatory limits (e.g., EPA, https://www.epa.gov/radiation/radiation-regulations-and-laws).

18 See July, 1954 GABRIEL test info at National Security Archive, http://nsarchive.gwu.edu/radiation/dir/mstreet/commeet/meet11/brief11/tab_i/br11i1a.txt

19 See the Memo to Members of the Advisory Committee on Human Radiation Experiments titled Documentary update on Project Sunshine "body snatching," http://nsarchive.gwu.edu/radiation/dir/mstreet/commeet/meet15/brief15/tab d/br15d2.txt

20 The Open Skies proposal included a summit between President Eisenhower (U.S.), Prime Minister Anthony Eden (Great Britain), Premier Edgar Faure (France), and Premier Nikolai Bulganin (FSU) to discuss information sharing that included the aerial surveillance of military sites. The sharing of this particular information through "Open Skies" acted as an oversight mechanism to ensure nations complied with arms control agreements. See the Arms Control Association, https://www.armscontrol.org/factsheets/openskies

21 At Pugwash, https://pugwash.org/1955/07/09/statement-manifesto/

22 Geagley also conducted oversight of radiation in foods. See the UNLV finding aid to the Geagley collection on nuclear safety, https://www.library.unlv.edu/speccol/ead/MS-00792_geagley.pdf

23 Hearings before the Special Subcommittee on Radiation of the Joint Committee on Atomic Energy, Congress of the United States, 85-1, May 27-June 7, 1957, https://catalog.hathitrust.org/Record/001621971

24 Today's standards pale in comparison, although critical questions continue to be asked of current regulatory standards. For example, the Nuclear Regulatory Agency's (NRC) limit to the public $0.1 \mathrm{rem} /$ year would produce an excess cancer in every 125 people exposed, and among the findings of the National Research Council's 2005 BEIR VII Phase 2 (Biological Effects of Ionizing Radiation) study is that women and children may be of higher risk of exposure to radiation, and "low doses of ionizing radiation, such as gamma rays and X-rays, are likely to pose some risk of adverse health effects." See the National Academies of Sciences, Engineering, and Medicine, https://www.nap.edu/webcast/webcast detail.php?webcast id=310 and and IEER's comments on the report, http://ieer.org/wp/wp-content/uploads/2005/07/BEIRVII-pressrelease.pdf. Also see John W. Gofman's seminal work Radiation-induced cancer from low-dose exposure: An independent analysis (Committee for Nuclear Responsibility, 1990) an 
Medical research and radiation politics: An oral history (Bancroft Library, 1982, https://archive.org/details/medicalresearchr00gofmrich).

25 An Appeal is at https://profiles.nlm.nih.gov/ps/retrieve/ResourceMetadata/MMBBFS; background information is available at the Pauling archive at Oregon State University, http://scarc.library.oregonstate.edu/coll/pauling/peace/narrative/page27.html

26 Doom excludes mention of the Soviet Union's "Tsar Bomba" that was detonated at Novaya Zemlya, near the Barents Sea on October 30, 1961. As Frank von Hippel notes, the testing of the Tsar Bomba "hastened the end of atmospheric testing in 1963." Also see Stephen Dowling's "The monster atomic bomb that was too big to use," BBC Future, August 16, 2017, http://www.bbc.com/future/story/20170816-the-monster-atomic-bomb-that-was-too-big-touse. Also not discussed in Doom are the five high-altitude tests conducted by DoD as part of Operation Dominic (e.g. Starfish Prime, July 9, 1962). See United States nuclear tests July 1945-September 1992, https://www.nnss.gov/docs/docs LibraryPublications/DOE NV209 Rev16.pdf

27 See the JFK Presidential Library, Nuclear Test Ban Treaty, https://www.jfklibrary.org/JFK/JFKin-History/Nuclear-Test-Ban-Treaty.aspx

28 See Trends in nuclear explosion monitoring research \& development - a physics perspective, http://www.osti.gov/scitech/10.2172/1355758

29 See the U.S. Department of State, https://www.state.gov/t/isn/trty/16281.htm

30 WIPP, on the other hand, is located in southern New Mexico, and is a repository for transuranic waste (TRU) generated at former AEC-current DOE facilities, including the former Rocky Flats Plant.

31 See Eileen Welcome's The plutonium files: America's secret medical experiments in the Cold War (New York: Dial Press, 1999) that in part led to the creation of the Advisory Committee on Human Radiation Experiments during the Clinton administration.

32 See Exposure of the American people to Iodine-131 from Nevada nuclear-bomb tests review of the National Cancer Institute report and public health implications. Accessed June 5, 2017. https://www.ncbi.nlm.nih.gov/books/NBK100848/ and Steven L. Simon, André Bouville, and Charles E. Land, "Fallout from nuclear weapons tests and cancer risk" (American Scientist 94, no. 1 (2006): 48-57).

More importantly, see the Senate Committee on Governmental Affairs, Permanent Subcommittee on Investigations, National Cancer Institute's management of radiation studies: Hearing before the Permanent Subcommittee on Investigations of the Committee on Governmental Affairs (105-2, S. Hrg 105-686, September 16. Washington: Government Printing Office, 1998). The hearing is important for two things: its "Timeline of events: National Cancer Institute's I-131 report," which illustrates the fourteen year lag to conduct I-131 studies mandated by Congress in 1982, well before the 1987 case Irene Allen v. the United States. Secondly, the opening statement by Sen. John Glenn, who spearheaded an investigation of the Institute's delay in publishing the I-131 report. Sens. Arlen Spector and Tom Harkin originally addressed the problem in a 1997 Senate Appropriations Subcommittee meeting (1).

33 See ICAN, About the Treaty to Prohibit Nuclear Weapons, http://www.icanw.org/campaignnews/about-the-treaty-to-prohibit-nuclear-weapons/

34 "UN conference adopts treaty banning nuclear weapons," UN News Centre, July 7, 2017. Accessed July 21, 2017, http://www.un.org/apps/news/story.asp?NewsID=57139 and ICAN, 
Positions on the Treaty, at http://www.icanw.org/why-a-ban/positions/

35 United States Mission to the United Nations. Joint press statement from the Permanent Representatives to the United Nations of the United States, United Kingdom, and France following the adoption of a Treaty Banning Nuclear Weapons. July 7, 2017, https://usun.state.gov/remarks/7892 